\title{
ASPEK REPRODUKSI DAN UMUR IKAN EKOR KUNING (Caesio cuning) YANG DI DARATKAN DI PELABUHAN PERIKANAN NUSANTARA SUNGAILIAT KABUPATEN BANGKA
}

\author{
Nirmala Sari ${ }^{1}$, Okto Supratman ${ }^{1}$, Eva Utami ${ }^{2}$ \\ ${ }^{1}$ Jurusan Manajemen Sumberdaya Perairan, FPPB, Universitas Bangka \\ Belitung, Kepulauan Bangka Belitung, Indonesia \\ ${ }^{2}$ Jurusan IImu Kelautan, FPPB, Universitas Bangka Belitung, Kepulauan \\ Bangka Belitung, Indonesia \\ E-mail :oktosupratman@gmail.com
}

Received July 2019, Accepted September 2019

\begin{abstract}
ABSTRAK
Ikan ekor kuning (Caesio cuning) salah satu jenis ikan karang dari famili Caesionidae, yang menjadi target penangkapan dengan bubu di Pelabuhan Perikanan Nusantara Sungailiat. Ikan ekor kuning memiliki nilai ekonomis penting. Informasi tentang aspek reproduksi ikan ekor kuning (Caesio cuning) diperlukan untuk pengelolaan yang berkelanjutan. Penelitian ini bertujuan untuk mengetahui aspek reproduksi ikan ekor kuning pada bulan Januari sampai Maret yang meliputi Rasio Kelamin (sex ratio), Tingkat Kematangan Gonad (TKG), Indeks Kematangan Gonad (IKG), Fekunditas, dan menganalisis umur ikan. Pengambilan sampel dilakukan pada bulan Januari sampai Maret 2019 di Pelabuhan Perikanan Nusantara Sungailiat dengan menggunakan metode random sampling. Hasil penelitian selama tiga bulan ini menunjukkan bahwa nilai rasio kelamin ikan ekor kuning jantan dan betina yaitu 1:1,032 yang berada pada tingkat kematangan I sampai dengan tingkat kematangan gonad IV. Nilai IKG ikan ekor kuning jantan berkisar antara 0,014\% $4,712 \%$ dan untuk betina antara $0,014 \%-7,784 \%$. Fekunditas ikan ekor kuning betina berkisar antara 5.523 - 49.987 butir dan memiliki umur 1 tahun dan 2 tahun, dimana panjang tubuh ikan sangat mempengaruhi umur ikan.
\end{abstract}

Kata Kunci : Ikan Ekor Kuning (Caesio cuning), Aspek Reproduksi, Umur lkan

\section{ABSTRACT}

REPRODUCTIVE ASPECTS AND AGE OF YELLOW-TAILED FISH (Caesio Cuning) LANDED AT SUNGAILIAT ARCHIPELAGO FISHING PORT IN BANGKA REGENCY. Reproductive aspects of yellow-tailed fish which are landed in the Pelabuhan Perikanan Nusantara Sungailiat in 
Bangka Regency. Yellow-tailed fish (Caesio cuning) is one type of reef fish from the Caesionidae family, which is the target of catching fish at the Pelabuhan Perikanan Nusantara Sungailiat. Yellow tail fish has important economic value. Information about the reproductive aspects of yellow tail fish (Caesio cuning) is needed for sustainable management. This study aims to determine the reproductive aspects of yellow tailed fish from January to March which include sex ratio, gonad maturity level, gonad somatic index, fecundity, and analyze the age of fish. Sampling was carried out from January to March 2019 at the Pelabuhan Perikanan Nusantara Sungailiat used the random sampling method. The results of this three-month study showed that the sex ratio of yellow-tailed fish male and female were 1: 1,032 which at the level of maturity I to the level of gonad maturity IV. The value of GSI male yellow-tailed fish ranges from $0.014 \%-4.712 \%$ and females between $0.014 \%-7.784 \%$. The fecundity of female yellow-tailed fish ranges from 5,523 - 49,987 grains and yellowtailed fish has age 1 year and 2 years, where the body length of fish greatly affects the age of fish.

Keywords :Yellow-tailed Fish (Caesio cuning), Reproductive Aspects, Age of fish

\section{PENDAHULUAN}

Provinsi Kepulauan Bangka Belitung merupakan daerah kepulauan dengan luas wilayah perairan mencapai 4 (empat) kali dari seluruh luas wilayah daratan. Luas daratan Provinsi Kepulauan Bangka Belitung yaitu sebesar $16.281 \mathrm{~km} 2$, dan luas perairan Provinsi Kepulauan Bangka Belitung diperkirakan $65.301 \mathrm{~km} 2$ dengan potensi perikanan tangkap sebesar 499.500 ton (Dinas Perikanan dan Kelautan Provinsi Kepulauan Bangka Belitung, 2005). Salah satu komoditas perikanan tangkap di wilayah perairan Provinsi Kepulauan Bangka Belitung tepatnya di Pelabuhan Perikanan Nusantara Sungailiat adalah ikan ekor kuning (Caesio cuning). Ikan Ekor Kuning merupakan salah satu jenis ikan karang dari famili Caesionidae, yang menjadi target penangkapan dengan bubu di Pelabuhan Perikanan Nusantara Sungailiat. Selain itu ikan ekor kuning memiliki nilai ekonomis penting yang dapat dimanfaatkan sebagai sumber pendapatan dan sumber makanan bagi masyarakat.

Produksi hasil tangkapan ikan Ekor Kuning (Caesio cuning) di Pelabuhan Perikanan Nusantara Sungailiat mengalami fluktuasi dari tahun ke tahun. Berdasarkan data dari Pelabuhan Perikanan Nusantara Sungailiat tahun 2018 hasil tangkapan ikan ekor kuning mengalami peningkatan dari tahun 2012 - 2013, dimana pada tahun 2012 hasil tangkapan ikan ekor kuning yaitu $208.985 \mathrm{~kg}$ dan pada tahun 2013 mencapai $382.411 \mathrm{~kg}$, kemudian terjadi penurunan hasil tangkapan di tahun berikutnya sehingga pada tahun 2017 hasil tangkapannya sebesar $183.057 \mathrm{~kg}$. Terjadinya ketidakstabilan hasil tangkapan ikan ekor kuning di Pelabuhan Perikanan Nusantara Sungailiat, maka perlu dilakukannya upaya pengelolaan. 
Okid (2000), menyatakan bahwa sumberdaya hayati akan terbuang bahkan dapat hilang apabila tanpa suatu pengelolaan, dan sebaliknya pula tanpa penelitian kita tidak akan mengetahui bagaimana cara mengelola sumberdaya hayati perairan dengan bijaksana. Informasi mengenai ikan Ekor Kuning di Provinsi Kepulauan Bangka Belitung sangat sedikit, hanya terbatas pada jumlah tangkapan, upaya penangkapan dan area penangkapannya, namun dalam pengelolaan perairan yang berkelanjutan pengetahuan mengenai reproduksi ikan merupakan hal yang sangat penting. Aspek reproduksi ikan itu sendiri terdiri dari rasio kelamin, tingkat kematangan gonad, indeks gonad dan fekunditas, yang berperan dalam menjaga kelangsungan hidup ikan dan menjaga stok ikan Ekor Kuning di suatu perairan agar dapat di manfaatkan dalam jangka waktu yang berkelanjutan. Ada beberapa penelitian aspek reproduksi ikan di Pelabuhan Perikanan Nusantara Sungailiat seperti ikan Kurisi (Persada et al., 2016), dan ikan Selar Kuning (Anjani et al., 2018), akan tetapi biologi reproduksi ikan Ekor Kuning belum pernah dilakukan penelitian. Oleh sebab itu, maka perlu dilakukannya penelitian mengenai aspek reproduksi ikan Ekor Kuning (Caesio cuning) yang didaratkan di Pelabuhan Perikanan Nusantara Sungailiat.

\section{MATERI DAN METODE}

\section{Waktu dan Lokasi Penelitian}

Pengambilan sampel ikan Ekor Kuning (Caesio cuning) dilaksanakan pada bulan Januari sampai dengan bulan Maret 2019 yang dilakukan di Pelabuhan Perikanan Nusantara Sungailiat, Kepulauan Bangka Belitung (Gambar 1). Identifikasi dan pengamatan aspek reproduksi ikan yang dilakukan di Laboratorium Manajemen Sumberdaya Perairan, Fakultas Pertanian Perikanan dan Biologi.
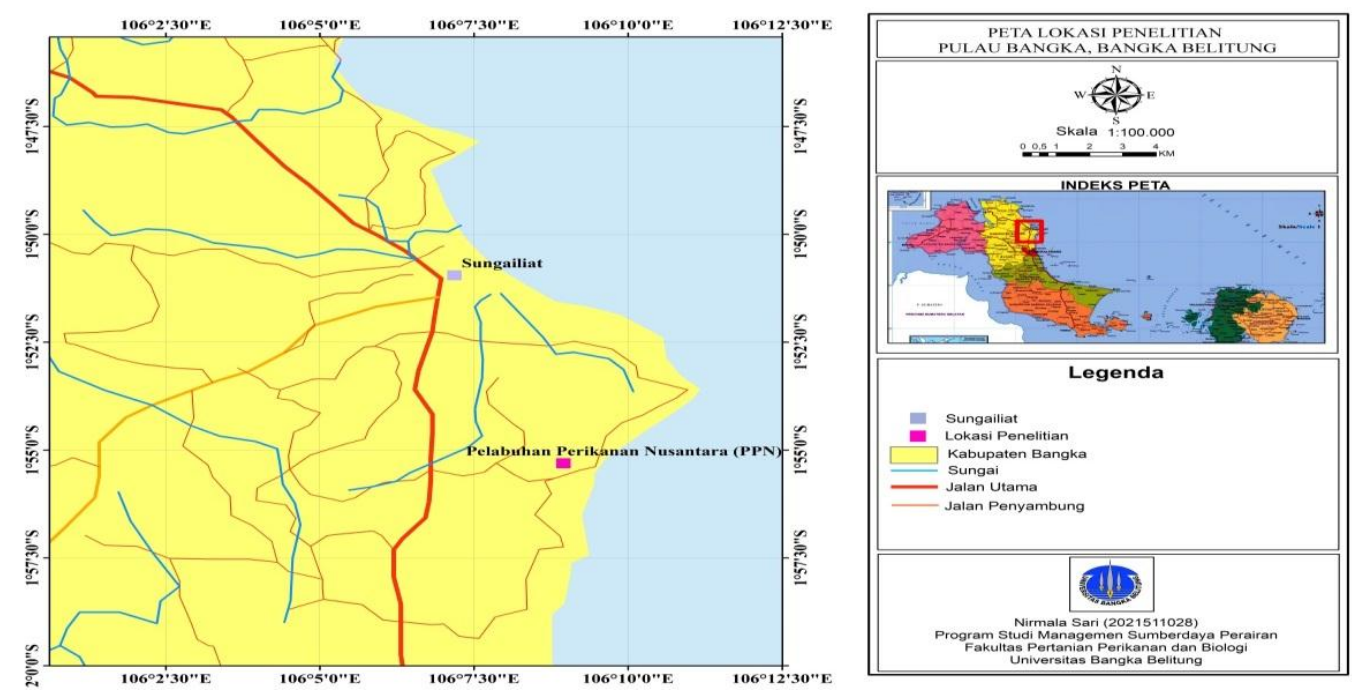

Gambar 1. Peta lokasi penelitian 


\section{Pengambilan Sampel Ikan}

Metode yang digunakan dalam pengambilan sampel ikan Ekor Kuning adalah metode random sampling yaitu pengambilan hasil tangkapan nelayan yang di daratkan di Pelabuhan Perikanan Nusantara Sungailiat, pengambilan sampel ikan dilakukan selama tiga bulan dan dalam satu bulan dilakukan sebanyak satu kali pengambilan sampel. Penentuan jumlah sampel ikan berdasarkan rumus Fauzi (2001), sebagai berikut:

$$
n=\frac{N \cdot Z^{2} \cdot 0,25}{\left[d^{2}(N-1)\right]+\left[Z^{2} \cdot 0,25\right]}
$$

Keterangan:

$$
\begin{array}{ll}
\mathrm{n} & \text { : Jumlah sampel } \\
\mathrm{N} & : \text { Jumlah individu dalam populasi } \\
1 & : \text { Konstanta } \\
0,25 & : \text { Konstanta } \\
\mathrm{d} & : \text { Persen kelonggaran ketidaktelitian ( nilai e: } 10 \% \text { ) } \\
\mathrm{Z} & : \text { Tingkat kebenaran } 90 \% \text { pada tabel Z (nilai Z: } 1,29 \text { ) }
\end{array}
$$

Hasil tangkapan ikan Ekor Kuning di Pelabuhan Perikanan Nusantara Sungailiat adalah $12.844 \mathrm{~kg} / \mathrm{bulan}$ (Pelabuhan Perikanan Nusantara Sungailiat, 2018). Jumlah individu dalam populasi adalah 64.220 ekor ikan. Jadi jumlah sampel yang diambil adalah 42 ekor ikan/bulan.

\section{Pengukuran Panjang dan Berat Ikan}

Setiap sampel ikan diukur panjang dan beratnya. Panjang total tubuh ikan diukur dari bagian mulut hingga bagian ujung ekor ikan menggunakan penggaris dengan ketelitian milimeter $1 \mathrm{~mm}$, sedangkan berat tubuh ikan ditimbang menggunakan timbangan digital dengan ketelitian 0,1 gram.

\section{Penentuan Rasio Kelamin}

Rasio kelamin ikan Ekor Kuning didapatkan dengan cara sampel ikan ditentukan jenis kelamin ikan dengan membedah ikan terlebih dahulu, kemudian jenis kelamin ikan ekor kuning dilakukan secara visual dengan melihat perbedaan dan ciri-ciri pada gonad ikan. Ikan Ekor Kuning jantan memiliki gonad berwarna keputihan susu yang berupa testes dan ikan ekor kuning memiliki gonad berwarna kekuningan yang berupa ovum. Setelah jenis kelamin ikan Ekor Kuning didapatkan jumlahnya, kemudian rasio jantan dan betina ini dapat dihitung menggunakan rumus sebagai berikut (Effendie, 1997): 
Keterangan:

$$
\mathrm{SR}=\frac{\mathrm{A}}{\mathrm{B}} \times 100 \%
$$

SR : Rasio kelamin (jantan dan betina)

A : Jumlah jenis ikan tertentu (jantan dan betina)

B : Jumlah total individu ikan yang ada (ekor)

\section{Penentuan Tingkat Kematangan Gonad Ikan}

Tingkat kematangan gonad ikan dapat dilihat pada ikan yang telah dibedah, kemudian gonad ikan diamati ukuran gonad dan bentuk morfologinya. Untuk mementukan TKG ikan Ekor Kuning,bentuk dan ciri ciri perkembangan gonad ikan dibandingkan dengan literatur ciri morfologis gonad ikan menurut Effendi, (1997) yang dapat dilihat pada Tabel 1.

Tabel 1. Penentuan tingkat kematangan gonad (TKG) ikan secara morfologi

\begin{tabular}{|c|c|c|}
\hline $\begin{array}{c}\text { Penentuan } \\
\text { TKG }\end{array}$ & Betina & Jantan \\
\hline TKG I & $\begin{array}{l}\text { Ovari seperti } \quad \text { benang, } \\
\text { panjangnya sampai ke depan } \\
\text { rongga tubuh serta } \\
\text { permukaannya licin. }\end{array}$ & $\begin{array}{l}\text { Testes seperti benang, } \\
\text { warna jernih dan ujungnya } \\
\text { terlihat dirongga tubuh. }\end{array}$ \\
\hline TKG II & $\begin{array}{l}\text { Ukuran ovari lebih besar, } \\
\text { warna ovari kekuning- } \\
\text { kuningan, dan telur belum } \\
\text { terlihat jelas }\end{array}$ & $\begin{array}{l}\text { Ukuran testes lebih besar } \\
\text { dan warna seperti susu }\end{array}$ \\
\hline TKG III & $\begin{array}{l}\text { Ovari berwarna kuning, dan } \\
\text { secara morfologi telur mulai } \\
\text { terlihat }\end{array}$ & $\begin{array}{l}\text { Permukaan testes tampak } \\
\text { bergerigi, warna makin } \\
\text { putih dan ukuran makin } \\
\text { besar }\end{array}$ \\
\hline TKG IV & $\begin{array}{l}\text { Ovari makin besar, telur } \\
\text { berwarna kuning, mudah } \\
\text { dipisahkan, butir minyak tidak } \\
\text { tampak dan mengisi } 0,5 \\
\text { rongga perut }\end{array}$ & $\begin{array}{l}\text { Dalam keadaan diawet } \\
\text { mudah putus, testes makin } \\
\text { pejal }\end{array}$ \\
\hline TKG V & $\begin{array}{l}\text { Ovari berkerut, dinding tebal, } \\
\text { butir telur sisa terdapat } \\
\text { didekat pelepasan }\end{array}$ & $\begin{array}{l}\text { Testes bagian belakang } \\
\text { kempes dan dibagian } \\
\text { dekat pelepasan masih } \\
\text { berisi }\end{array}$ \\
\hline
\end{tabular}




\section{Penentuan Indeks Kematangan Gonad}

Peningkatan IKG akan meningkat seiring dengan meningkatnya tingkat kematangan gonad ikan tersebut. Untuk mendapatkan IKG, ikan terlebih dahulu dibedah, kemudian ambil gonad ikan, setelah gonad didapatkan gonad ikan ditimbang bobot totalnya (BG) dengan timbangan digital.Untuk menghitung IKG ikan dapat menggunakan rumus (Effendie, 2002):

$$
I K G=\frac{B G}{B T} \times 100 \%
$$

Keterangan :

$\mathrm{BG}=$ Berat Gonad (gram)

$\mathrm{BT}=$ Berat Tubuh (gram)

\section{Penentuan Fekunditas}

Fekunditas adalah jumlah telur masak sebelum dikeluarkan pada waktu ikan memijah. Fekunditas hanya dapat dihitung pada ikan betina yang memiliki TKG III dan IV. Fekunditas didapatkan dengan terlebih dahulu membedah ikan ekor kuning, kemudian diambil gonad nya dan ditimbang dengan menggunakan timbangan digital. Gonad tersebut dinyatakan sebagai berat gonad utuh $(\mathrm{G})$, gonad tersebut kemudian dipotong menjadi tiga bagian yaitu interior, tengah dan posterior. Salah satu bagian gonad diambil dan ditimbang dengan timbangan digital yang disebut sebagai berat gonad contoh (Q). Gonad contoh ikan tersebut kemudian diencerkan dengan $10 \mathrm{ml}$ aquades (V), dan dikocok hingga merata setelah itu diambil $1 \mathrm{ml}$ dari pengenceran tersebut dan dihitung jumlah telurnya $(\mathrm{X})$. Rumus yang dipakai untuk menghitung fekunditas adalah (Effendie, 1997):

$$
F=\frac{G \times V \times X}{Q}
$$

Keterangan:

$\mathrm{F} \quad$ : Fekunditas

G : Berat gonad utuh (gram)

$\mathrm{V} \quad$ : Volume pengenceran $(\mathrm{ml})$

$\mathrm{X} \quad$ : Jumlah telur dalam $1(\mathrm{ml})$

Q : Berat gonad contoh (gram)

\section{Penentuan Umur Ikan}

Penentuan umur ikan Ekor Kuning (Caesio cuning) dalam penelitian ini diidentifikasi dengan menggunakan metode otolith, yakni menggunakan otolith sagitta. Penentuan umur ikan dengan menggunakan otolith merupakan teknik terbaik dan akurat sampai saat ini dibandingkan 
dengan teknik lain seperti menggunakan sisik, atau struktur keras lainnya dari ikan karena. Pembedahan kepala ikan dilakukan dengan menggunakan alat bedah seperti pisau gunting dan pinset. Kedua operculum ikan dibuka dan bagian insang dikeluarkan, kemudian bagian ujung tulang belakang dipatahkan dengan hati-hati dan sepasang otolith sagitta akan terlihat yang terletak didalam sebuah kantong yaitu kantong sacculus. Otolith sagitta yang telah didapatkan kemudian diletakkan didalam cawan petri kemudian di cuci sampai bersih, setelah itu otolith di letakkan di object glass untuk diteliti dibawah mikroskop (Suharti, 2002).

\section{HASIL DAN PEMBAHASAN}

\section{Rasio Kelamin}

Rasio kelamin merupakan perbandingan antara jumlah ikan jantan dengan jumlah ikan betina.jumlah ikan Ekor Kuning (Caesio cuning) yang diamati yaitu sebanyak 126 ikan Ekor Kuning, dimana jumlah ikan Ekor Kuning jantan berjumlah 62 ekor ikan dan ikan betina sebanyak 64 ekor ikan (Tabel 2).

Tabel 2. Rasio kelamin ikan ekor kuning (Caesio cuning) betina dan jantan pada Bulan Januari - Maret 2019

\begin{tabular}{lccl}
\hline \multirow{2}{*}{ Bulan } & \multicolumn{2}{c}{ Jenis Kelamin } & \multirow{2}{*}{ Rasio Kelamin } \\
\cline { 2 - 3 } & Jantan & Betina & \\
\hline Januari & 23 & 19 & $1,21: 1$ \\
Februari & 22 & 20 & $1,1: 1$ \\
Maret & 17 & 25 & $1: 1,47$ \\
\hline Total & 62 & 64 & $1: 1,032$ \\
\hline
\end{tabular}

Perbandingan rasio kelamin ikan Ekor Kuning jantan dan betina sebesar 1: 1,03 menyimpang dari pernyataan Effendie (2002), perbandingan rasio kelamin ikan jantan dan betina di suatu perairan dikatakan seimbang yaitu $1: 1$, dimana jumlah ikan jantan dan ikan betina memiliki jumlah yang sama. Memiliki jumlah ikan betina lebih banyak dibandingkan dengan ikan jantan di perairan Pelabuhan Perikanan Nusantara Sungailiat masih dapat digolongkan kedalam keadaan yang ideal untuk suatu populasi ikan, karena pada saat ikan melakukan pemijahan jumlah ikan betina harus lebih banyak dibandingkan dengan ikan jantan. Ikan jantan dapat menghasilkan banyak sperma yang harus dibuahi oleh ikan betina, sedangkan satu ekor ikan betina hanya dapat dibuahi 1 buah sperma, jadi jumlah sperma yang dihasilkan satu ekor ikan Ekor Kuning jantan lebih banyak dibandingkan dengan jumlah telur yang dihasilkan oleh ikan Ekor Kuning betina sehingga pada saat pemijahan jumlah ikan ekor kuning betina harus lebih banyak dibandingkan dengan ikan jantan dan dimungkinkan satu ekor ikan jantan dapat membuahi dua ekor ikan betina (Santoso, 2009). Menurut Bal dan Rao (1984) dalam 
Gustomi et al. (2016), perbandingan jumlah ikan jantan dan betina yang berada pada kondisi yang seimbang diperlukan untuk mempertahankan kelangsungan hidup dalam suatu populasi, atau setidaknya ikan betina lebih banyak.

Menurut Putri dan Nurlita (2012), perbedaan jumlah ikan jantan dan betina disuatu perairan disebabkan oleh aktivitas ikan didalam perairan, kemampuan beradaptasi, faktor genetik, makanan, faktor penangkapan, migrasi, adanya perubahan jenis ikan baru pada suatu populasi yang sudah ada dan pola pertumbuhan. Menurut Saputra et al. (2009), apabila perbandingan rasio kelamin ikan jantan dan ikan betina sama atau rasio kelaminnya lebih besar betina hal ini menunjukkan bahwa populasi ikan tersebut disuatu perairan masih ideal atau seimbang untuk menjaga kelestariannya. Apabila disuatu perairan tersebut rasio kelamin ikan jantan lebih besar dari pada rasio kelamin ikan betina, maka hal tersebut tergolong tidak seimbang dan akan menyebabkan bahaya bagi populasi ikan tersebut. Sebagaimana menurut Suhendra et al. (2017), Rasio ikan jantan tinggi dalam suatu populasi dapat mengganggu kelestarian spesies. Saat rasio jantan lebih banyak tetapi telur yang dihasilkan betina sedikit meski keberadaan sel sperma melimpah di perairan karena jumlah betina sedikit maka akan menghasilkan anakan atau keturunan yang sedikit. Perbedaan jumlah Ikan jantan dan betina yang tertangkap diduga karena perbedaan tingkah laku, penyebaran Ikan jantan betina tidak merata serta faktor penangkapan.

\section{Tingkat Kematangan Gonad (TKG)}

Tingkat kematangan gonad merupakan tahapan perkembangan gonad sebelum dan sesudah ikan melakukan pemijahan. TKG I testes berwarna jernih dan memiliki bentuk seperti benang,TKG II ukuran testes lebih besar dari pada TKG I, warna putih susu dan lebih jelas dari TKG I. TKG III permukaan testes yang bergerigi, warna testes semakin putih susu dan ukuran testes lebih besar dari TKG II, kemudian untuk TKG IV testes mekin pejal, ukuran testes semakin besar dan bila diawetkan testes akan cepat putus (Gambar 2). Testes ikan Ekor Kuning jantan memiliki bentuk lebih kecil dibandingkan dengan bentuk ovari pada betina. TKG I ikan Ekor Kuning betina yaitu ovari seperti benang dan mempunyai permukaan yang licin, TKG II memiliki ukuran ovari lebih besar dari TKG I, warna ovari lebih kekuningan, telur belum terlihat jelas secara morfologi dan pembuluh darah tidak terlihat. TKG III ukuran ovarium semakin bertambah besar, warna semakin kuning, secara morfologi telur mulai terlihat dan pembuluh darahnya sudah mulai terlihat namun belum terlihat jelas, untuk TKG IV ukuran ovari semakin besar, telur sudah terlihat jelas dan berwarna kuning, mudah dipisahkan, ovarium ikan Ekor Kuning betina mengisi 0,5 rongga perut ikan dan pembuluh darah pada ovarium sudah terlihat sangat jelas (Gambar 3). 

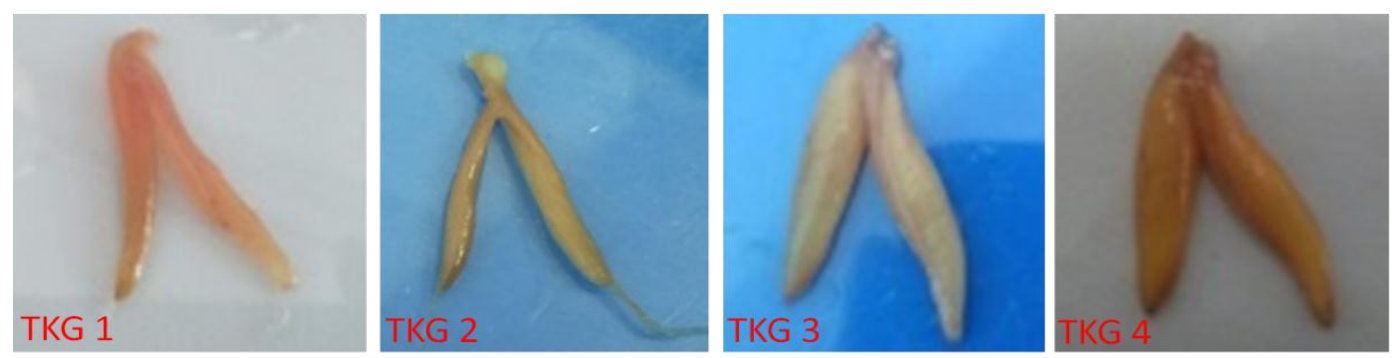

Gambar 2. Morfologi gonad ikan ekor kuning (Caesio cuning) jantan
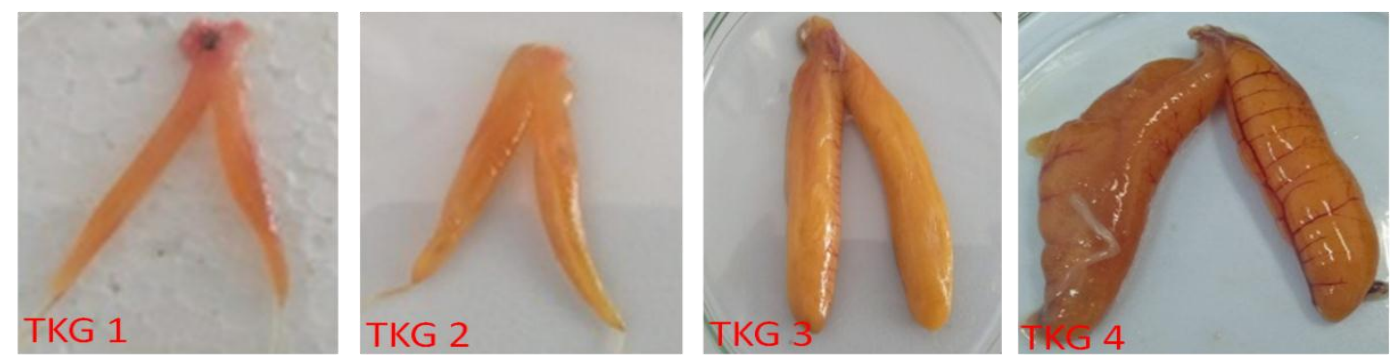

Gambar 3. Morfologi gonad ikan ekor kuning (Caesio cuning) betina

Hasil tingkat kematangan gonad ikan Ekor Kuning (Caesio cuning) selama penelitian menunjukkan bahwa ikan Ekor Kuning mengalami perkembangan gonad dari bulan Januari hingga bulan Maret 2019 dan ikan Ekor Kuning yang paling banyak mengalami matang gonad (TKG IV) yaitu terjadi pada bulan Maret (Gambar 4). Ikan Ekor Kuning yang didaratkan di Pelabuhan Perikanan Nusantara Sungailiat, lokasi penangkapannya berada di Perairan Rebo, Perairan Matras dan Perairan Tuing. Jumlah ikan Ekor Kuning betina yang matang gonad pada bulan Maret lebih banyak dibandingkan dengan ikan Ekor Kuning jantan. Puncak pemijahan ikan Ekor Kuning terjadi pada bulan Maret yang ditandai dengan banyaknya jumlah ikan yang memiliki TKG III dan IV, sebagaimana Menurut penelitian Prihatiningsih dan Bambang (2018), musim pemijahan ikan ekor kuning diprediksi dua kali dalam setahun yaitu mulai bulan Mei dan September hingga satu atau dua bulan berikutnya.

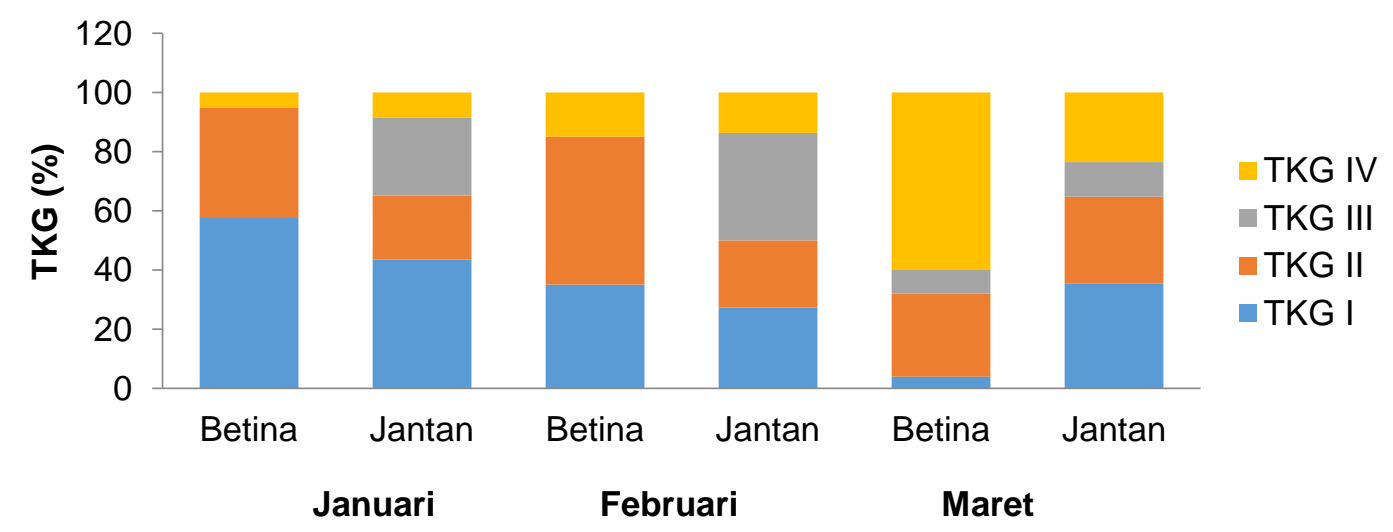

Gambar 4. Tingkat kematangan gonad ikan ekor kuning (Caesio cuning) jantan dan betina selama penelitian 


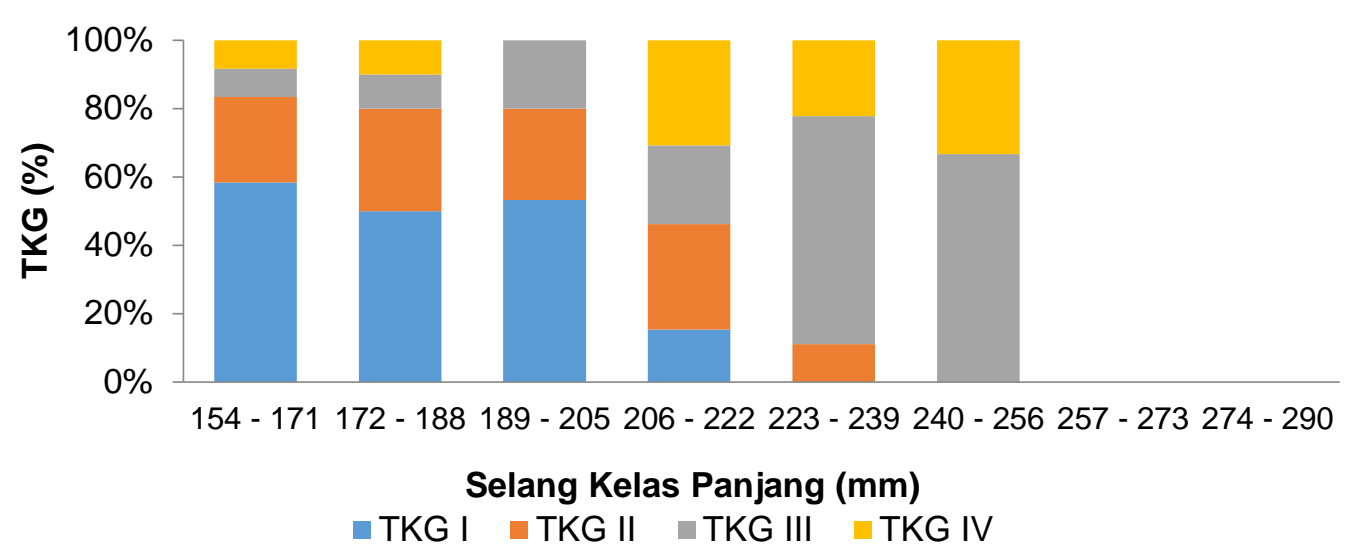

Gambar 5.Tingkat kematangan gonad ikan ekor kuning (Caesio cuning) jantan berdasarkan selang kelas panjang $(\mathrm{mm})$

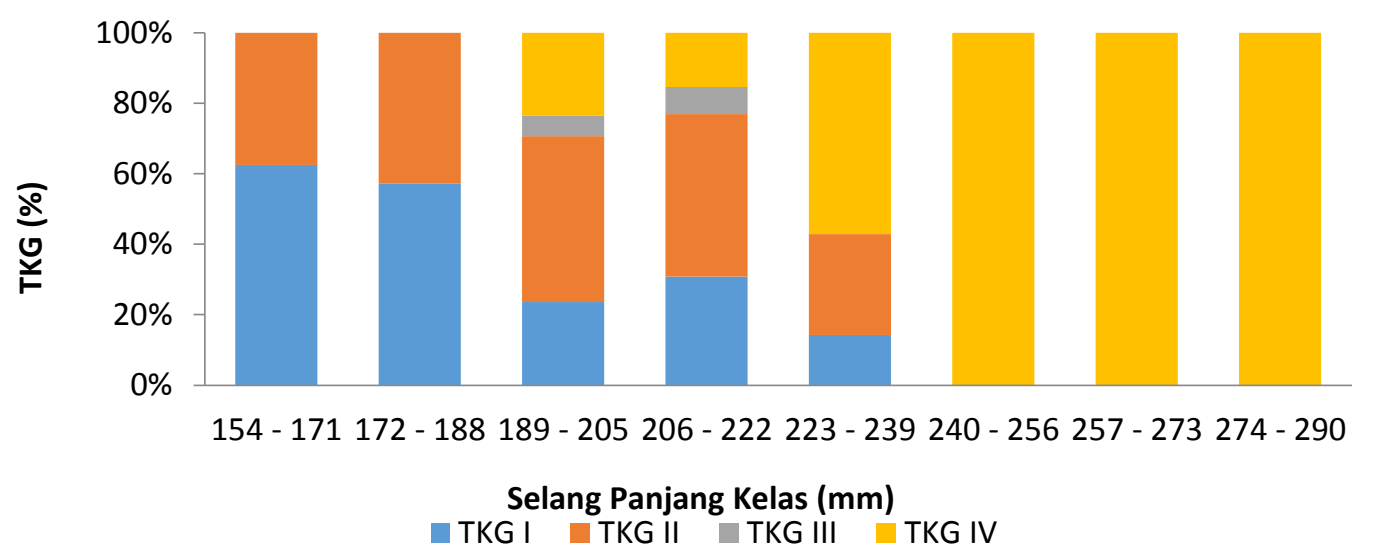

Gambar 6.Tingkat kematangan gonad ikan ekor kuning (Caesio cuning) betina berdasarkan selang kelas panjang $(\mathrm{mm})$

Ikan Ekor Kuning jantan mencapai ukuran matang gonad (TKG IV) pada ukuran selang kelas panjang $154-171 \mathrm{~mm}$, sedangkan ikan Ekor Kuning betina pada selang kelas panjang $189-205 \mathrm{~mm}$ (Gambar 5 dan Gambar 6). Secara keseluruhan dapat dilihat bahwa ikan Ekor Kuning jantan cenderung lebih cepat matang gonad dibandingkan dengan ikan Ekor Kuning betina, hal tersebut dapat dilihat ikan Ekor Kuning jantan mencapai TKG III pada ukuran 154 - $171 \mathrm{~mm}$ dan ikan Ekor Kuning betina pada ukuran $189-205 \mathrm{~mm}$. Perbedaan ukuran ikan jantan dan betina pada saat matang pertama kali matang gonad disebabkan oleh ikan Ekor Kuning jantan lebih aktif bergerak mencari makan, pola pertumbuhan ikan dan faktor lingkungan.

Menurut Kantun et al. (2011),ukuran ikan waktu pertama kali matang gonad berhubungan dengan pertumbuhan dan faktor lingkungan. Adapun faktor-faktor yang mempengaruh saat pertama kali matang gonad adalah 202arrin internal yaitu perbedaan spesies, umur, ukuran, serta sifat-sifat fisologis dari ikan tersebut. Selain itu fator eksternal juga mempengaruhi seperti makanan, suhu, arus, dan adanya individu yang berlainan jenis kelamin yang berbeda dan dapat memijah yang sama. 
Faktor utama yang mempengaruhi TKG pada daerah yang bermusim empat adalah suhu dan makanan, tetapi untuk di daerah tropis suhu tidak berpengaruh. Dalam penelitian Persada et al. (2016), Bulan Maret adalah awal bulan peralihan dari musim barat ke musim timur sehingga masih termasuk kedalam kriteria musim barat. Kondisi suhu perairan masih rendah.Rendahnya suhu perairan dapat menyebabkan ikan mengalami kematangan gonad yang lama.

\section{Indeks Kematangan Gonad (IKG)}

Nilai indeks kematangan gonad ikan Ekor Kuning jantan dan betina tertinggi terjadi pada bulan Maret yaitu untuk ikan Ekor Kuning jantan sebesar 0,758\% dan untuk ikan Ekor Kuning betina sebesar 3,632\%. Hubungan antara tingkat kematangan gonad dengan nilai indeks kematangan gonad ikan Ekor Kuning jantan dan betina menunjukkan bahwa nilai indeks kematangan gonad ikan Ekor Kuning jantan betina tertinggi terjadi pada ikan dengan TKG IV yaitu untuk ikan Ekor Kuning jantan sebesar 2,277\% dan betina sebesar 5,327\% (Gambar 7 dan Gambar 8).

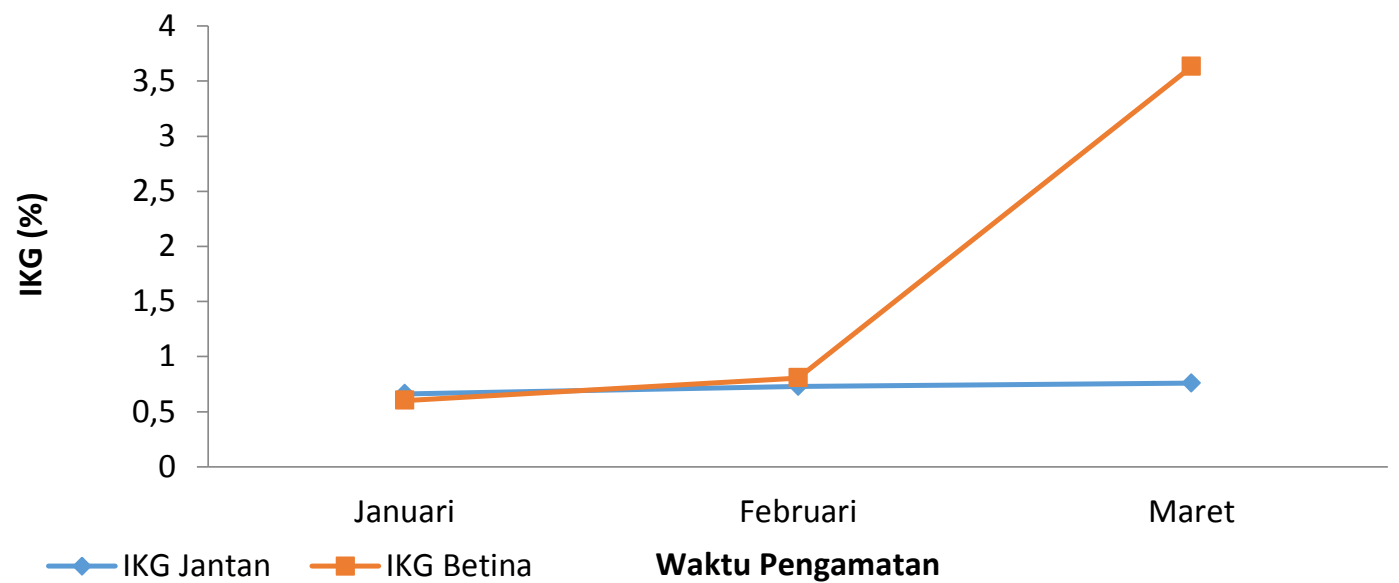

Gambar 7. Nilai indeks kematangan gonad ikan ekor kuning (Caesio cuning) berdasarkan bulan pengamatan

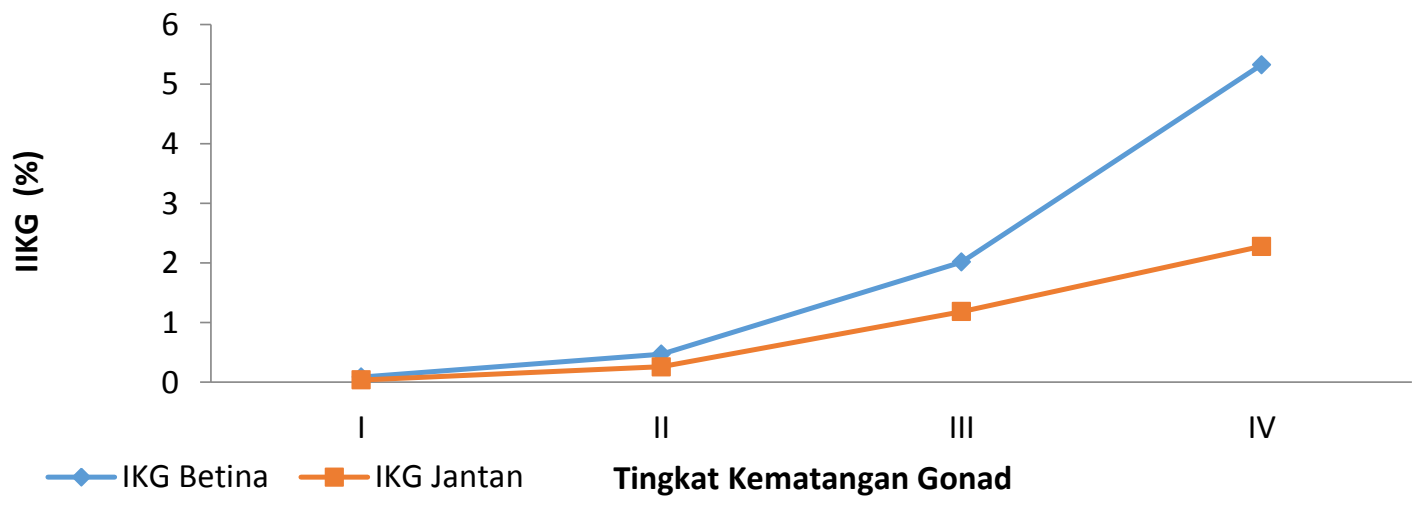

Gambar 8. Nilai indeks kematangan gonad berdasarkan tingkat kematangan gonad ikan ekor kuning (Caesio cuning) 
Indeks kematangan gonad adalah nilai dalam persen (\%) sebagai hasil dari perbandingan berat gonad ikan dengan berat tubuh ikan. Nilai indeks kematangan gonad ikan Ekor Kuning jantan dan betina mengalami peningkatan dari TKG I hingga TKG IV. Nilai IKG ikan Ekor Kuning jantan, lebih kecil dibandingkan betina hal ini terjadi karena ikan Ekor Kuning betina memiliki bobot gonad yang lebih besar dibandingkan dengan ikan Ekor Kuning jantan. Menurut Effendie (2002), umumnya pertambahan berat gonad pada ikan betina sebesar $10-25 \%$ dari berat tubuh sedangkan pada ikan jantan sebesar 5-10\%.

Tingginya nilai IKG pada bulan Maret karena ikan Ekor Kuning berada pada tingkat kematangan gonad III dan IV serta memiliki berat gonad yang lebih tinggi dibandingkan dengan bulan - bulan sebelumnya. Nilai rata - rata indeks kematangan gonad ikan Ekor Kuning tertinggi juga terjadi pada ikan Ekor Kuning yang berada pada ikan dengan TKG IV, semakin rendah TKG suatu ikan maka nilai IKG ikan tersebut juga akan semakin kecil. Menurut Sembiring et al. (2014), sejalan dengan perkembangan gonad, gonad semakin bertambah besar sampai mencapai maksimum ketika ikan memijah, dan perubahan nilai IKG erat hubungannya dengan tahap perkembangan telur.

\section{Fekunditas}

Fekunditas adalah jumlah telur masak sebelum dikeluarkan pada saat ikanmemijah.Nilai fekunditas tertinggi terjadi pada ikan Ekor Kuning betina dengan panjang total berkisar antara $274-290 \mathrm{~mm}$ dan berat tubuh sebesar 285 - 290 gram dengan nilai fekunditas yaitu 49.987 butir (Tabel 3). Kegunaan dari fekunditas ini yaitu untuk mengetahui seberapa banyak jumlah telur ikan yang akan menghasilkan spesies baru atau anak ikan.

Tabel 3. Hasil fekunditas berdasarkan panjang total dan berat tubuh ikan ekor kuning (Caesio cuning) betina

\begin{tabular}{cccc}
\hline No. & $\begin{array}{c}\text { Panjang Total Ikan } \\
(\mathrm{mm})\end{array}$ & $\begin{array}{c}\text { Berat Tubuh Ikan } \\
(\mathrm{gram})\end{array}$ & $\begin{array}{c}\text { Rata - Rata } \\
\text { Fekunditas (Butir) }\end{array}$ \\
\hline 1 & $189-205$ & $85-159$ & 16.505 \\
2 & $206-222$ & $118-168$ & 9.967 \\
3 & $223-239$ & $155-189$ & 20.261 \\
4 & $240-256$ & $181-189$ & 13.164 \\
5 & $257-273$ & $186-244$ & 27.248 \\
6 & $274-290$ & $285-290$ & 49.987 \\
\hline
\end{tabular}

Menurut Effendie (2002), fekunditas secara tidak langsung dapat menaksir jumlah anak ikan yang dihasilkan dan jumlah telur yang dikeluarkan adalah rantai penghubung antara satu generasi dengan generasi berikutnya. Umumnya ikan teleostei perairan laut memiliki tingkat fekunditas tinggi, mencapai ribuan sampai jutaan setiap ikan betinanya 
pertahun.Hasil penelitian fekunditas ikan Ekor Kuning (Caesio cuning) betina yang didapatkan yaitu berkisar antara 5.523 - 49.987 butir.Nilai fekunditas yang tinggi ini berarti ikan Ekor Kuning memiliki potensi reproduksi yang tinggi pula, sehingga berpengaruh pula pada tingginya kesedian stok dan rekruitmen ikan Ekor Kuning.

\section{Umur Ikan Ekor Kuning}

Umur ikan Ekor Kuning pada peneitian ini yaitu menghitung lingkaran tahunan yang terdapat pada otolith ikan Ekor Kuning. Ikan yang memiliki umur satu tahun memiliki satu garis lingkaran tahunan dan yang berumur dua tahun memiliki dua buah garis lingkaran tahunan. Ikan Ekor Kuning jantan yang berumur satu tahun memiliki panjang total berkisar antara 160 - $200 \mathrm{~mm}$, sedangkan untuk umur 2 tahun panjang total tubuh ikan berkisar antara $200-243$ mm. Ikan Ekor Kuning betina pada umur 1 tahun memiliki panjang total berkisar antara $160-229 \mathrm{~mm}$, sedangkan untuk umur ikan Ekor Kuning dengan umur ikan 2 tahun panjang total tubuh ikan berkisar antara 200 - $290 \mathrm{~mm}$ (Tabel 4). Komposisi umur dalam suatu populasi atau komunitas ikan pada suatu perairan sangat penting untuk diketahui, terutama jika dihubungkan dengan produksi yang kaitannya dengan pengelolaan ikan sebagai sumberdaya perairan. Data umur yang dihubungkan dengan data panjang dapat memberikan keterangan tentang umur pada waktu ikan pertama kali matang gonad, pertumbuhan dan reproduksi (Persada et al. 2016).

Tabel 4. Umur ikan ekor kuning (Caesio cuning) berdasarkan panjang total $(\mathrm{mm})$

\begin{tabular}{ccc}
\hline Kelamin Ikan & Umur Ikan (Tahun) & Kisaran Panjang Total $(\mathrm{mm})$ \\
\hline Jantan & 1 & $160200 \mathrm{~mm}$ \\
Betina & 2 & $200-243 \mathrm{~mm}$ \\
& 1 & $160-229 \mathrm{~mm}$ \\
& 2 & $200-290 \mathrm{~mm}$ \\
\hline
\end{tabular}

\section{KESIMPULAN}

Rasio ikan Ekor Kuning diperoleh sebesar 1 : 1,032 dan pada bulan Januari - Maret ikan Ekor Kuning jantan dan betina berada pada TKG I TKG IV. Nilai indeks kematangan gonad ikan Ekor Kuning semakin besar ketika ikan dalam keadaan akan memijah, Fekunditas ikan Ekor Kuning betina pada saat penelitian berkisar antara 5.523 - 49.987 butir.Umur ikan Ekor Kuning yang ditemukan selama penelitian yaitu ikan Ekor Kuning dengan umur 1 tahun dan umur 2 tahun, hubungan antara panjang total dengan umur ikan Ekor Kuning sangat erat karena pertambahan panjang total ikan Ekor Kuning diikuti dengan pertambahan umur ikan Ekor Kuning. 


\section{UCAPAN TERIMA KASIH}

Penulis ucapkan terima kasih kepada pengelola Laboratorium Manajemen Sumberdaya Perairan, Universitas Bangka Belitung, yang telah memfasilitasi tempat dan meminjamkan peralatan untuk pengambilan data, sehingga penelitian ini dapat terlaksana.

\section{DAFTAR PUSTAKA}

Anjani, F.D., W. Adi, \& E. Utami. 2018. Aspek Reproduksi Ikan Selar Kuning (Selaroides leptolepis) Yang Didaratkan Di Pelabuhan Perikanan Nusantara Sungailiat. Akuatik. 12(1): 26-34.

Dinas Kelautan dan Perikanan Provinsi. 2005. Laporan Tahunan 2005. Dinas Kelautan dan Perikanan Provinsi Kepulauan Bangka Belitung. Pangkal Pinang.

Effendie, M.I. 1997. Biologi Perikanan. Yayasan Pustaka Nusantara.: Yogyakarta.

Effendie, M.I. 2002. Biologi Perikanan. Yayasan Pustaka Nusantara: Yogyakarta.

Fauzi, A. 2001. An Economic Analysis of The Surplus Production: An Application for Indonesian Small Pelagic Fishery. Paper Presented At The National Seminar Persada. Bogor 20 Januari 2001.

Gustomi, A., Sulistiono \& Yonvitner. 2016. Bilogi Reproduksi Ikan Belida (Notopterus notopterus Pallas, 1769) Di Kolong-Bendungan Simpur, Pulau Bangka. Jurnal IImu Pertanian Indonesia. 21(1):56-62.

Kantun, W., S.A. Ali, A. Malawa, \& A. Tuwo. 2011. Ukuran Pertama Kali Matang Gonad Dan Nisbah Kelamin Tuna Madidihang (Thunnus albacares) Di Perairan Majene-Selat Makassar. Jurnal Balik Diwa. 2(2):1-6.

Okid, P.A. 2000. Permasalahan Pengelolaan Keanekaragaman Hayati di Indonesia. Jurnal Aspirin.1(1):36-40.

Persada, L.G., E. Utami, \& D. Rosalina. 2016. Aspek Reproduksi Ikan Kurisi (Nemipterus furcosus) Yang Didaratkan Di Pelabuhan Perikanan Nusantara Sungailiat. Akuatik. 10. 02: 46-55.

Prihatiningsih, I.N.E., \& S. Bambang. Biologi Reproduksi, Pertumbuhan dan mortalitas Ikan Ekor Kuning (Caesio Cuning Bloch, 1791) di Perairan Natuna. Jurnal Bawal widya riset Perikanan tangkap. 10(1):1-15. 
Putri, R.M., \& A. Nurlita. 2012. Aspek Reproduksi Ikan Kerapu Macan (Epinephelus sexfasciatus) di Perairan Glondonggede Tuban. Jurnal Sains dan Seni. 1(1):27-31.

Santoso, L. 2009. Biologi Reproduksi Ikan Belida (Chitala lopis) di Sungai Tulang Bawang, Lampung. Jurnal Berkala Perikanan Terubuk. $37(1): 38-46$.

Saputra, S.W., P. Soedarsono \& G.A. Sulistawati. 2009. Beberapa Aspek Biologi Ikan Kuniran (Upeneus sp.) di Perairan Demak. Jurnal Saitek Perikanan. 5(1):1-6.

Sembiring, S.B.M., R. Andamari, A. Muzaki, I.K. Wardana, J.H Hutapea, \& W.W Astuti. 2014. Perkembangan Gonad Ikan Kerapu Sunu (Plectropomus leopardus) yang Dipelihara Dalam Keramba Jaring Apung. Jurnal Ilmu dan Teknologi Kelautan Tropis. 6(1):53-61.

Suharti, S.R. 2002. Menentukan Umur Ikan Melalui Mikrostruktur Otolith. Jurnal Oseana. 2(1):1-8.

Suhendra, C., E. Utami, \& Umroh. 2017. Biologi Reproduksi Ikan Keperas (Cyclocheilichthys apogon) Di Perairan Sungai Menduk Kabupaten Bangka. Akuatik. 11(1):1-11. 